\title{
Wireless Telegraphy at the German Universal Exhibition in Ústí nad Labem in $1903[1]$
}

\section{T. Okurka}

This paper focuses on the transmission of wireless telegraphy between Ústi nad Labem and Teplice during the German Universal Exhibition in Usti nad Labem in 1903. Though this was not the first transmission of wireless telegraphy in Austria, as some newspapers claimed, it was probably the first transmission of wireless telegraphy over a large distance presented to the public in Bohemia. The idea of presenting wireless telegraphy at this exhibition was promoted by Wilhelm Biscan, director of the Elektrotechnikum school in Teplice at that time. The telegraph was installed by the Allgemeine Elektrizitäts-Gesellschaft in Berlin. The device used the Slaby-Arco system.

Keywords: History of technology, electrical engineering, wireless telegraphy, exhibitions.

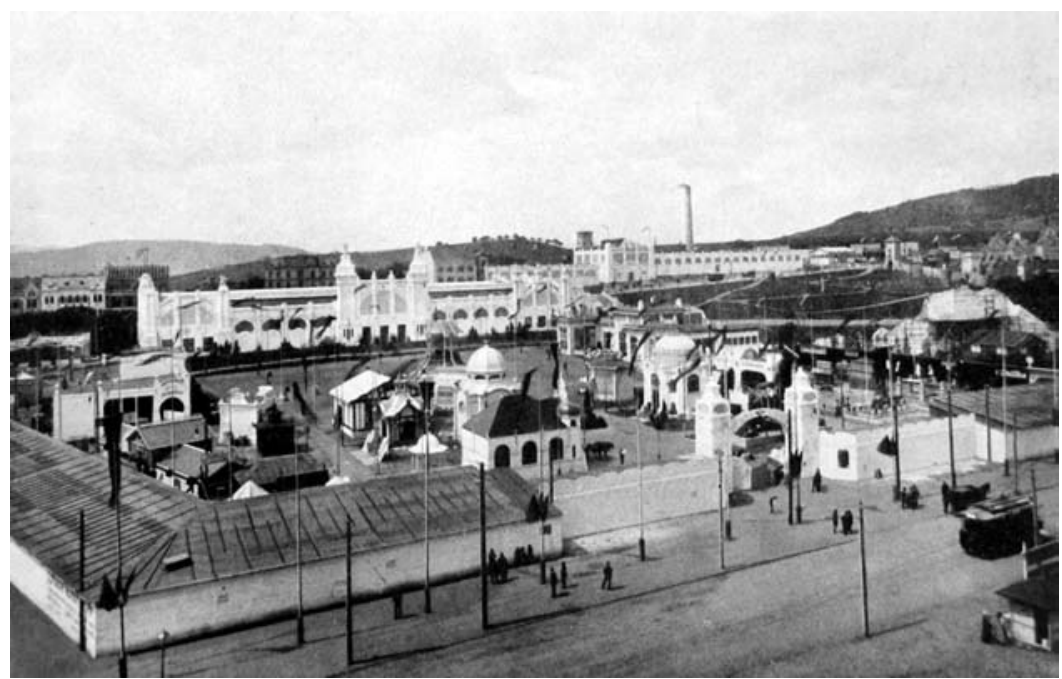

Fig. 1: Exhibition grounds in Ústí nad Labem in 1903

Industrial and universal exhibitions played a significant role before World War I. This refers both to world exhibitions, which became a global phenomenon in the second half of the $19^{\text {th }}$ century, and to minor national and regional exhibitions. These were of high importance for the economy since they fostered commercial intercourse. These events attracted large numbers of people and provided a source of knowledge and entertainment. Political importance can also often be attributed to them as well.

Dissemination of scientific and technological progress was one of the main aims of the exhibitions. Each of the world exhibitions presented some novelties of science and technology (which were often revolutionary) to the general public for the first time. The innovations included Bell's telephone in Philadelphia 1876, Edison's phonograph in Paris 1889, and radio in Chicago 1893. "In spite of the haphazard and often purely fortuitous method of gaining knowledge by these exhibitions, it is doubtful that a more efficient promoter of technology could have been devised at the time." [2] This applies in first place to the world expositions but national and regional exhibitions also in many cases presented noteworthy innovations. Wireless telegraphy at the German Universal Exhibition in Ústí nad Labem in 1903 is a good example.

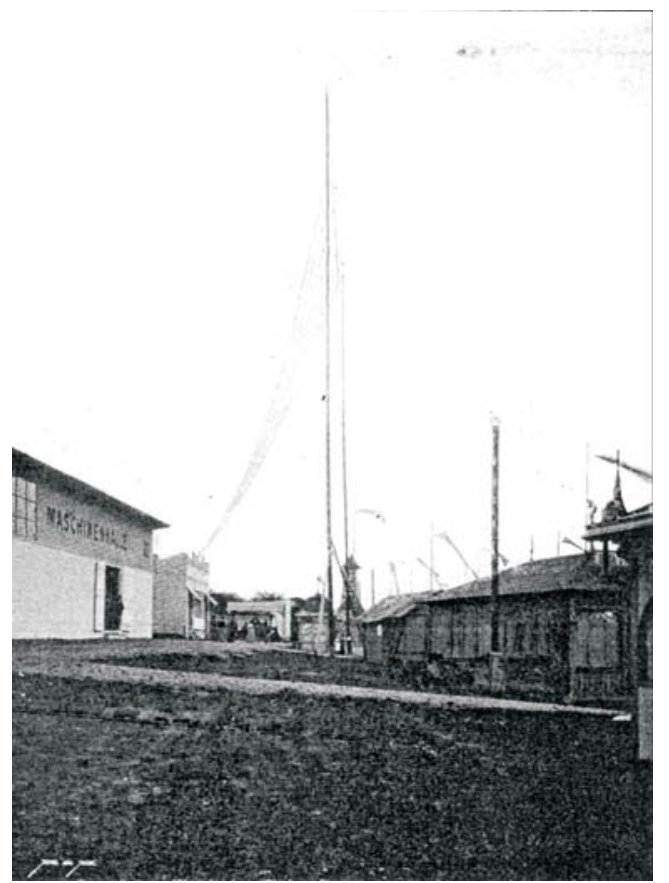

Fig. 2: Pavilion of the wireless telegraphy in Ústí nad Labem 


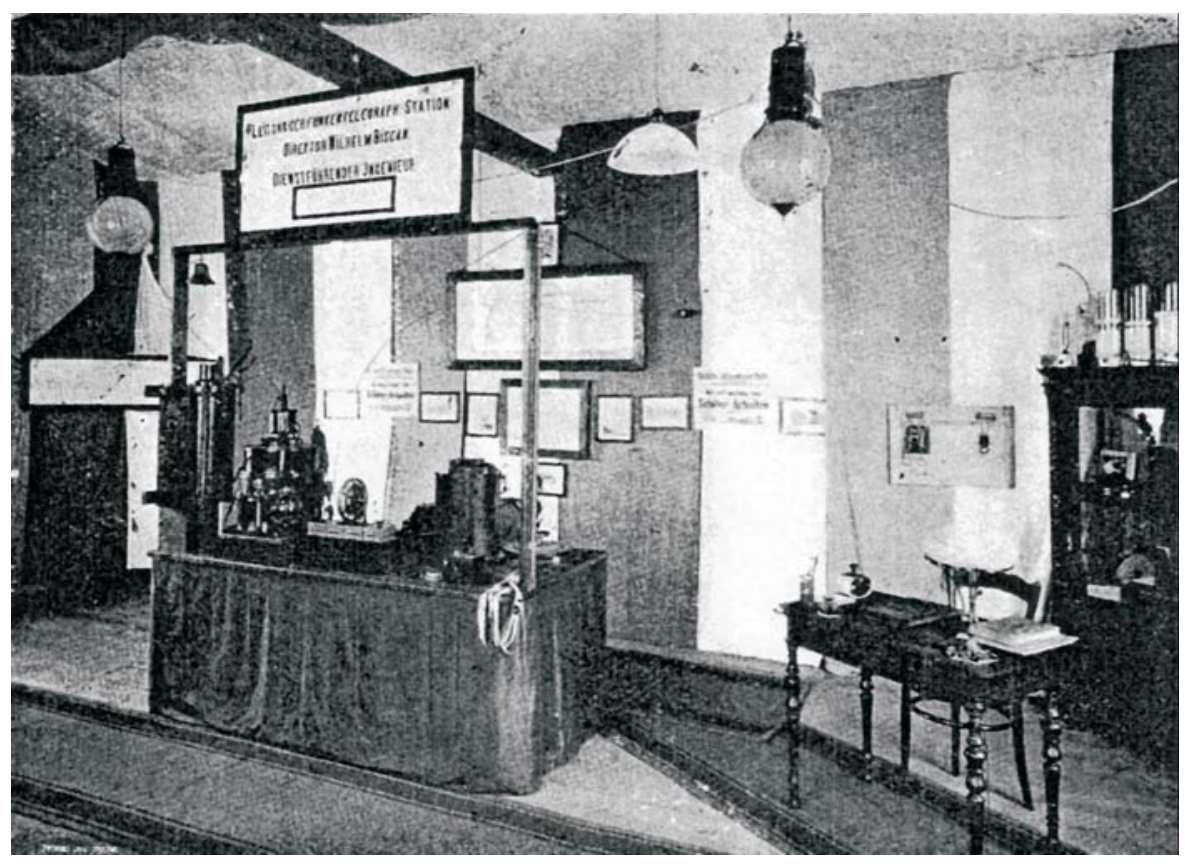

Fig. 3: Interior of the pavilion

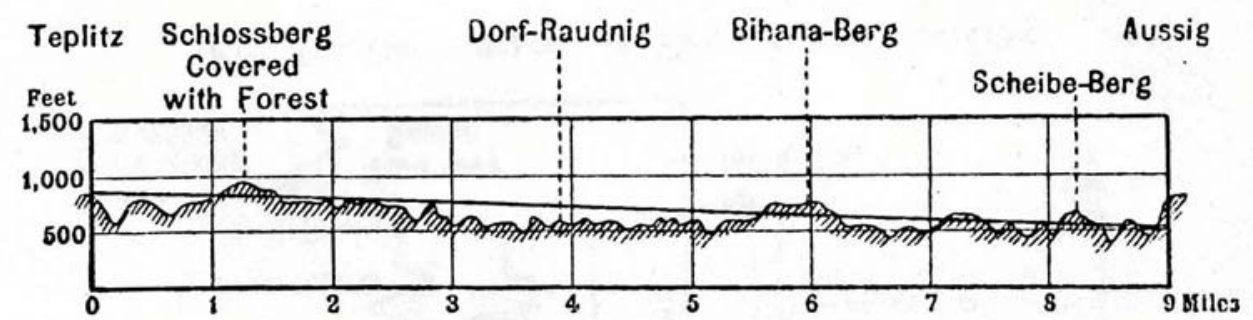

Fig. 4: Profile of country between Teplice and Ústí nad Labem

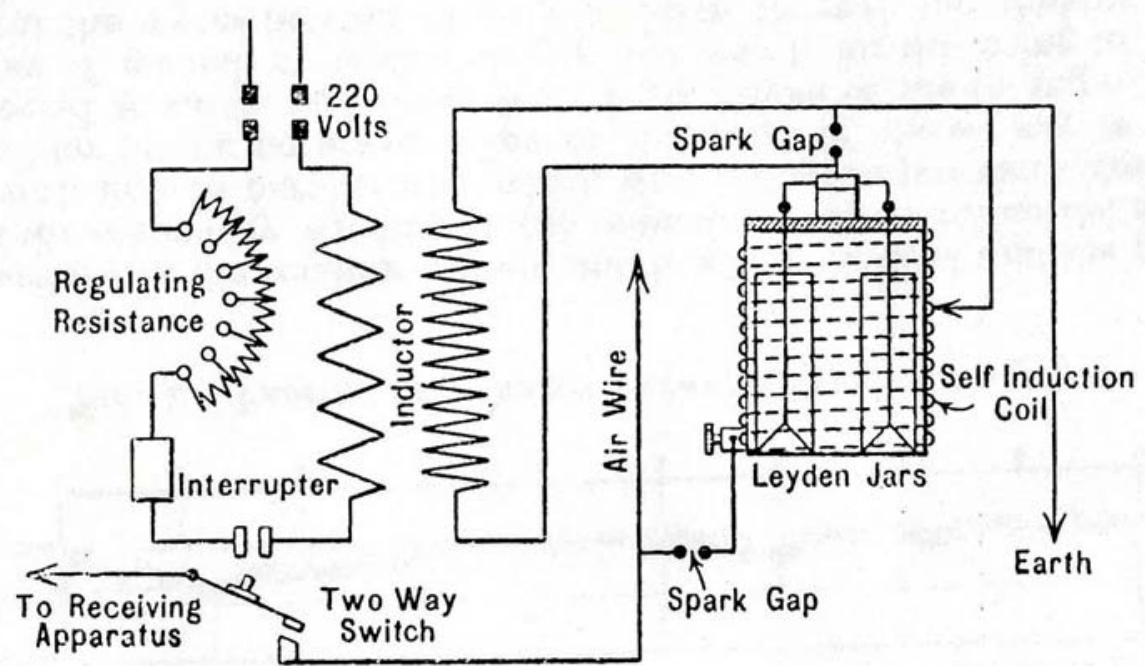

Fig. 5: Connections at transmitting station 


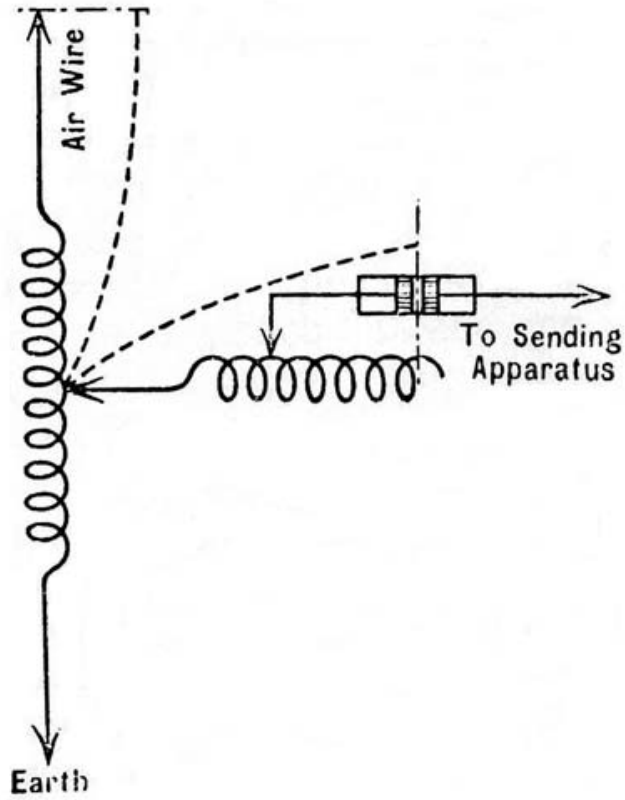

Fig. 6: Connections at receiving station

The Ústí nad Labem exhibition was held by the local Association of Craftsmen. It did not focus solely on crafts, but also comprised industry, arts, agriculture, transportation, education, etc. It was one of the largest exhibitions before World War I in the German regions of Bohemia. Nine hundred exhibitors took part and six hundred thousand visitors attended the exhibition in the course of three months. It attracted extensive attention of the local press and various German newspapers in Bohemia, Austria and abroad. However, the Czech press - due to high national feelings in Bohemia - neglected this German exhibition almost completely.

The idea of presenting wireless telegraphy at the exhibition in Ústí nad Labem was promoted by Wilhelm Biscan, founder and director of the Elektrotechnikum school in Teplice [3]. The telegraph was installed by the Allgemeine Elektrizitäts-Gesellschaft in Berlin. At the exhibition grounds in Ústí nad Labem a small pavilion was built with two high poles. The second station was situated in the Elektrotechnikum in Teplice. The distance between these stations was $14 \mathrm{~km}$. In the course of the exhibition there was a successful wireless telegraph connection between these two towns. The wireless telegraphy pavilion was an object of extraordinary attention among visitors and the press; it was one of the highlights of the exhibition. The device used the Slaby-Arco system, which was a rival to the Marconi system. The purpose of the pavilion was to show the principle of wireless telegraphy to the visitors. Mr. Biscan explained it, for example, to the Bohemian governor Karl Coudenhove [4].

At the opening ceremony on June $20^{\text {th }}$, the organizers read out a message of greetings from Teplice. This was said to be the first wireless telegram sent in Austria [5]. That grandiose claim of primacy was, however, somewhat exaggerated. It was certainly not the first successful transmission of wireless telegraphy in Austria. Successful relays had been transmitted earlier by Siemens \& Halske in Vienna, and there were also radiotelegraphic transmissions by the navy near Pula [6]. Besides, it is not sure that the transmission on the opening day of the exhibition was successful. The primacy of this telegram was questioned by the daily newspaper Deutsche Volkszeitung. However, this nationalistic and antisemitic newspaper is not a very reliable source of information. In an article under the title "Humbug", the newspaper wrote that because of unprofessional procedures the device did not work and the organizers just read out the text of the greeting message that they had known in advance. Several days later, an expert from Berlin had to come to Ústí nad Labem to repair the device. Only then - according to Deutsche Volkszeitung - "the first-ever wireless telegram in Austria, on which so much rubbish was prattled by the Jewish newspapers, could be received". [7]

However, it is not of great importance whether the device actually worked on the opening day. It is obvious that the radiotelegraphic connection between Ústí nad Labem and Teplice worked in the following weeks. Evidence of this can be found in the German newspapers in Bohemia and in technical journals in Vienna and abroad. The Vienna Zeitschrift für Post und Telegraphie affirmed that "the device at the exhibition grounds in Ústi nad Labem works perfectly". [8] The journal of the Vienna Electrical Association Zeitschrift für Elektrotechnik published a detailed description of the wireless telegraphy between Ústí nad Labem and Teplice [9]. A shorter version of this article was published by the British journal The Electrician [10]. These articles did not declare this relay to be the first wireless transmission in Austria, but they appreciated that the relay succeeded although the district, on account of the various hills, was not very favourable for wireless telegraphy. Information on the wireless telegraphy at the exhibition in Ústí nad Labem was also published by the Czech technical journal Technický obzor [11]. However, other Czech newspapers and magazines neglected this success absolutely.

There is no doubt that wireless telegraphy was successfully presented to the general public at the exhibition in Ústí nad Labem in 1903. However, present-day technical literature refers to the transmission between Prague and Carlsbad during the exhibition of the Prague Chamber of Commerce in 1908 as the first presentation of wireless telegraphy to the general public in the Bohemian Lands [12]. The relay between Ústí nad Labem and Teplice fell into oblivion. This is probably because it took place in the German part of Bohemia. Generally, Czechs neglected such events in this region of the country. If a success like this could not be interpreted as a national event no significance was attributed to it. This oblivion can also be explained by the fact that wireless telegraphy was not widely used after the presentation in Ústí nad Labem.

The wireless telegraphy pavilion at the German Universal Exhibition in Ústí nad Labem 1903 was probably the first place in the Bohemian Lands where a transmission of wireless telegraphy over a large distance was presented to the general public. Before that, only experiments over a short distance had been carried out (for example, the successful experiments of František Křižík in the year 1902) [13]. There are enough reliable reports on the relays between Ústí nad Labem and Teplice to provide testimony to the beginning of wireless telegraphy in the Bohemian Lands.

After the exhibition, Wilhelm Biscan used the same device for experiments on wireless transmission in a train. A non-moving wireless station was placed in the railway station in Teplice and a mobile wireless station was installed in a special carriage of a passenger train on the Ústí nad Labem - Teplice - Chomutov railway line. The apparatus in the train received 
a message from the railway station at a distance of $7 \mathrm{~km}$. According to the technical journals, this was the first successful transmission in a train in the lands of the Habsburg monarchy [14].

\section{References}

[1] This paper is based on a chapter on wireless telegraphy in my thesis on the German Universal Exhibition in Ústí nad Labem 1903, which was published in the year 2005: Okurka, T.: Všeobecná německá výstava v Ústí nad Labem 1903 [German Universal Exhibition in Ústí nad Labem 1903], Ústí nad Labem 2005.

[2] Ferguson, E. S.: Expositions of Technology 1851-1900. In: Technology in Western Civilization. The Emergence of Modern Industrial Society Earliest Times to 1900. Kranzberg, M., Pursell, C. W. (eds.), vol. 1, New York 1967, p. 725.

[3] For more about this school see: 20 Jahre Elektrotechnikum 1895-1915. Ein Gedenkblatt als Beilage zum Programm der Anstalt, Teplitz, 1915.

[4] 20 Jahre Elektrotechnikum, p. 3-4.

[5] Aussiger Tagblatt, 22. 6. 1903, p. 4; Bohemia, 21. 6. 1903, p. 5 .

[6] See many articles in: Zeitschrift für Post und Telegraphie, vol. 10, 1903; other successful experiments in Austria are described on the websites of the company Telekom Austria: www.aon.at.
[7] Deutsche Volkszeitung, 9. 7. 1903, p. 4.

[8] Zeitschrift für Post und Telegraphie, 10.7. 1903, p. 159-160.

[9] Zeitschrift für Elektrotechnik, 4. 10. 1903, p. 569-570.

[10] The Electrician, 13. 11. 1903, p. 136.

[11] Technický obzor, 16. 12. 1903, p. 337.

[12] Mayer, D.: Pohledy do minulosti elektrotechniky [Views of History of Electrical Engineering], České Budějovice 1999, p. 249; Nemrava, A.: Sdělovací technika [Communication Engineering]. In: Studie o technice v českých zemích 1800-1918 [Essays on Technology in Bohemian Lands 1800-1918], Jílek, F. (ed.), vol. 4, Praha 1986, p. 236.

[13] Technický obzor, 25. 2. 1903, p. 56-57.

[14] Zeitschrift für Post und Telegraphie, 1. 12. 1903, p. 271-272; Technický obzor, 16. 12. 1903, p. 337; Elektrotechnische Zeitschrift, 3. 12. 1903, p. 996.

Tomáš Okurka

e-mail: tomas.okurka@seznam.cz

Institute of Economic and Social History

Charles University

Faculty of Philosophy and Arts

Celetná 20

11642 Prague 1, Czech Republic 